TANJA ŠLJIVAR

tanjasljivar13@gmail.com

(D) https://orcid.org/0000-0003-4575-0043

\title{
Self-referential reading in the performance Rose is a rose is a rose is a rose by Ivana Sajko
}

\author{
Autoreferencijalno čitanje $\mathbf{u}$ izvedbi drame \\ Rose is a rose is a rose is a rose Ivane Sajko
}

\begin{abstract}
Summary: In this text I offer an analysis of the performance Rose is a rose is a rose is a rose by Ivana Sajko, by comparing the notion of the "performative reading" (used here to designate reading aloud, on stage, by the performers, in the frame of the fully realized theater production) with the notion of the "self-referential reading" (used by Sajko as a tryout of generating the new relation between the author and her text through reading it aloud in front of the audiences, by herself). Reading aloud is here affirmed as an autonomous and legitimate performative and theatrical act.
\end{abstract}

Keywords: performative reading, self-referential reading, Ivana Sajko, playwriting, temporality

Sažetak: U radu nudim analizu izvedbe drame Rose is a rose is a rose is a rose Ivane Sajko uspoređujući pojam „performativnoga čitanja“ (koje u ovom kontekstu označuje čitanje izvođača naglas, na pozornici, u okviru u potpunosti završene kazališne izvedbe) s pojmom „autoreferencijalnog čitanja“ (koje Sajko upotrebljava kao pokušaj stvaranja novog odnosa između autorice i njezina teksta, čitajući sama taj tekst naglas pred publikom). Čitanje naglas ovdje se potvrđuje kao autonoman i legitiman performativni i kazališni čin.

Ključne riječi: performativno čitanje, autoreferencijalno čitanje, Ivana Sajko, dramsko pisanje, temporalnost 
In this article ${ }^{1}$ w would like to examine Ivana Sajko's ${ }^{2}$ performance Rose is a rose is a rose is a rose $e^{3}$ as an example of the performative practice I denote as performative reading and explain at length in my M.A. Thesis Oral reading as a performative practice. Performative reading is a practice in opposition to silent reading and a strategy loosely connected to the practices of poetry readings, audio books, and staged readings of plays. It is a theatrical tool most similar, but not identical, to reader's theater. Such reading aloud would ideally be a performative strategy that neither interprets the text, nor interrogates it, nor offers critical approaches towards it, but equates oral reading and performative act, that is to say equates reading and performance. It is onstage reading used, not in the rehearsal process, but as a performative strategy incorporated into fully-realized theater production - the point at which we generally expect texts to be memorized by the performers delivering them.

I saw the performance to be analyzed here on video, recorded at the $45^{\text {th }}$ BITEF festival, in September 2011. I will explore the (auto)poetic implications of a situation in which the author performs her own texts, by reading them aloud and employing the staging strategy she refers to as "self-referential reading". Furthermore, I will analyze the specific temporality of writing a text for the stage in comparison to the temporality of performing the same text by its author on the stage, and I will try to explain how the time of writing and reading and the time of staging/performing collide in such

1 The article is an adapted chapter from my M.A. THEsIs: Oral reading as a performative practice with which I completed my studies at the Institute for the Applied Theater Science at JLU Giessen, Germany in autumn 2017. The thesis was mentored by Prof. Dr. Gerald Siegmund and Prof. Dr. Bojana Kunst.

${ }^{2}$ Ivana Sajko is a writer, director and performer, born in 1975 in Zagreb. She studied dramaturgy at the Academy of Drama Arts, and she obtained a M.Sc. at the Faculty of Philosophy in Zagreb. She has presented her literary and theater work through lectures and staged readings in many established cultural institutions such as Centre Pompidou, Comedie Française Paris, Theatre Festival d'Avignon, Literarisches Colloquium Berlin, Literaturhaus München, Magasin3 Stockholm etc., while her plays were staged in venues such as Schauspiel Frankfurt, Konzert Theatre Bern, Staatstheater Braunschweig, Malthouse Theatre Melbourne, Tristan Bates Theatre London etc. She has won several awards for playwriting and literature, and in 2013, she received the Chevalier de l'ordre des Arts et Lettres medal by the French Ministry of Culture. She was working in BAD co. as a dramaturge, playwright, director and performer until 2005, when she started to direct and perform as an individual artist, mainly with musicians, experimenting with interdisciplinary approaches to problems of staging plays. She was the City Writer of Graz (213/14) and a guest of DAAD residence program in Berlin (2016/17) (this unpublished version of the biography was provided by Ivana Sajko).

${ }^{3}$ Further in the text, I will refer to Ivana Sajko's text Rose is a rose is a rose is a rose** with an abbreviated form - Rose*, while I will use the abbreviation Rose ${ }^{* *}$ for the performance of the text. 
a specific theater act. Rose is a rose is a rose is a rose is a text commissioned by Steierischer Herbst festival in 2008. It premiered on October 23, 2008 in Graz, at the same festival, staged by Dutch-Belgian actors collective Wunderbau, and it was subsequently staged both in Germany (Theaterhalle 7, Munich) and in Switzerland (Luzerner Theater). The performance I am writing about premiered on March 9, 2010 and was a co-produced between Zagrebačko Kazalište Mladih, Zagreb and Istarsko Narodno Kazalište, Pula.

The text Rose* is subtitled as a score which is of a core importance for the subsequent staging, too. It is a non-linear, postdramatic theater text, a polyphonic monologue revolving around the topic of love, or more precisely the impossibility of a love encounter without an appurtenant disjunction. The love encounter happened one Wednesday evening in a club, when lovers were not the only ones "burning", but a bus in a provincial city was also set on fire - the fire, ignited by a Molotov cocktail, and the dissatisfaction of the working class provincial youth - the one in which "The quiet people will burn up quietly"4. Similar to her 2015 novel titled Love novel, the background of the love story in Rose includes social riots, disasters and changes, as well as poverty: "The history of their town is a chronology of such tragedies" ${ }^{\prime \prime}$. Dramatic time and space and characters and scenes are categories not applicable to this theater text, while the notion of "performance of writing" is: "When I write, the very act of writing is as close to me as my subject. [...] The text is a necessary trace of my performance. [...] All this pornography of the text and of the performance could be reduced to a fundamental need - to express oneself in one's own language" ${ }^{\prime \prime}$. By changing constantly from ich to $e r$ form of narration, by employing multi-focal narrative perspectives of the events, by referencing other authors, sources and events (Alain Badiou's text What is Love?, verses from Revelation, 8: 7-127, Rembrandt's painting The

${ }^{4}$ I. SAjко: Rose is a rose is a rose is a rose. In: Welt retten / Saving the world. English translation T. BRLEK. Graz, Steirischer Herbst, 2008, p. 28.

${ }^{5}$ Ibidem, p. 36.

${ }^{6}$ Ibidem, p. 12.

${ }^{7}$ Let us be reminded here of Mladen Dolar's account of the use of voice for reading sacral texts aloud in churches: "One cannot perform a religious ritual without resorting to the voice in that sense: one has, for example, to say prayers and sacred formulas labialiter, viva voce, in order to assume them and make them effective, although they are all written down in sacred texts and everybody (supposedly) knows them by heart. Those words, carefully stored on paper and in memory, can acquire performative strength only if they are relegated to the voice, and it is as if the use of the voice will ultimately endow those words with the character of sacredness and ensure their ritual efficacy, in spite of - or, rather, because of - the fact that the use of the voice does not add anything to their content" (M. Dolar: A voice and nothing more. Cambridge Massachusetts, MIT Press, 2006, p. 108). Sajko most certainly does not perform the sacred ritual when she 
Night Watch, the 1931 marathon foxtrot dancing of Ritof-Boudreaux couple or several world-wide riots which happened at the beginning our century), Sajko constantly writes a text that is evading fixed meanings and uniformed formal attributes. Simultaneously with Rose*, she writes her own "text about text" ${ }^{\prime \prime}$. Rose from the title is a reference to a famous verse from Gertrude Stein's 1913 poem Sacred Emily and, as such, does not simply pay an homage to Stein, but is also a stylistic and formal decision.

By elevating the phonetics of the words above (their) semantics, Sajko is producing a theater text or, to be precise, a score which will be used as a theater material in its staging in tension with and in opposition to its alleged meaning. Constant multiplication of literary motifs and subversion of their meanings, previously established in the text, are a large part of Sajko's "performance of writing". For example, rose is not only the title reference to Stein, but also a pattern on the living room couch upon which a love scene takes place. Literary motifs keep reappearing in other media used in the performance as well - e.g. in two videos made by S. B. Narath. In the first one, Narath edits numerous documentary materials of different worldwide riots, and in the second, an animated green bus explodes while driving through the black background representing the province, and the fire devours the blackness and the town. Sajko also repeatedly comments on the process of writing and describes the most desirable staging of the text, both in bracketed stage directions and in the tissue of the very text. The anticipation of love of her characters (which are rather speaking positions than dramatic characters) is analogous to author's own anticipation of the performance/ staging of the text: "What remains is an endeavour. A state of anticipation. The need for love. Textual and physical. That would be the subject. An endeavour to write. An endeavour to speak love. The same text was assigned to both myself and the characters" ${ }^{\prime \prime}$. Text is filled with an intrinsic wish to be staged, to be read out loud, as poetry should be read, and to be listened to passionately, as music should be listened - „And the rest is music ${ }^{\prime \prime}{ }^{10}$. In Rose**, on the stage of Bitef theater, four men and a woman all stand behind

reads aloud the lines from the Bible such as: "And the seven angels which had the seven trumpets prepared themselves to sound" (I. SAJко: Rose is a rose is a rose is a rose. In: Welt retten / Saving the world..., p. 22). She ends the passage ironically and quickly saying "....and so on". By doing so, while she looks directly at the audience, she subverts the established practice of reading in churches. Unlike priests, she does add content to the words by the way she reads them. Interesting intensification of such subversion in this specific performance of Rose $e^{* *}$ is created by the fact that Bitef theater is located in an abandoned church.

\footnotetext{
${ }^{8}$ I. SAјко: Rose is a rose is a rose is a rose..., p. 13.

${ }^{9}$ Ibidem, p. 12.

${ }^{10}$ Ibidem, p. 13.
} 
black music stands, with textual and musical scores placed on them. Musicians and authors of the musical score are: K. Pauk - bass guitar, V. Peternel - production and sound managing on the computer and mixing console, A. Sinkauz - bass guitar and double bass, and N. Sinkauz - electric guitar. The soundscape of the piece consisted of a number of diverse sounds: reading voices, speaking voices, whispering voices, live music performance, sampled pop songs, children songs and electronic music, pre-recorded composed music, speech and reading modulated through specially adjusted microphones, onomatopoeic sounds which provide ironic background to the scenic action, sounds of breaking glass and explosions. All of them are at times played and performed separately, and at times, they overlap, thus creating a complex sound dramaturgy in the piece.

Two additional stands are on stage too: one placed at the proscenium with no performer behind it and one easel stand. On the easel, there is a reproduction of The Night Watch - its position on the stand, seen in the context of signifying patterns of the piece, implies that the painting, too, is to be understood as a score. Sajko, the writer, describes the painting in Rose $e^{*}$ and turns it into text, and Sajko, the director, places the painting's reproduction on the stand on stage in Rose ${ }^{* *}$ and turns it into music. On the stand placed on the proscenium there are papers turned towards the audience with printed titles of respective scenes. The first one says: "vocal warm up". Two things are implied by this subtitle: it could be a piece resembling a rehearsal, or pretending to be one, and it is a musical theater piece, possibly even a concert: "Love story that could be a political drama. Performance that might be a rock concert. And Ivana Sajko, who will be all of it"11. At the very beginning of the piece, under the working lights that are enhancing the atmosphere of the rehearsal (light design: A. Cavlek), five performers are alternately repeating sentences from the following introductory passage of the Rose*:

You and I. He and she. Sometimes we. Sometimes they. But always the same.

On stage. On a dance-floor. On the street. On the tenth floor of the skyscraper.

Right now. Also much later. And earlier. In memory.

Circling the razed site of a catastrophe. The text. Myself ${ }^{12}$.

${ }^{11}$ Announcement for the piece on the website of Zagreb Youth Theater, http://www. zekaem.hr/predstave/rose-is-a-rose-is-a-rose-is-a-rose/ [access: 11.10.2017].

${ }^{12}$ I. SAjко: Rose is a rose is a rose is a rose..., p. 15. 
Who gets to speak on Ivana Sajko's stage? Who "circles the text" she wrote? You and I? He and she? We? They? Or is it the author, or the director, or the performer who speaks to us here and now, or only one of these authorial positions at certain moments, or all of them at the same time? On stage, no professional actors are present, the only performers are a dramatist and four musicians and it is them who speak. The instability of the speaking subject is assigned twice to Sajko, by Sajko: "The same text was assigned to both myself and the characters". Then, she changes the paper on the note stand turned towards the audience. This one says "Love Scene". And then she continues reading her own text aloud.

\section{Playwrights' stage directions:}

\section{How to read aloud our texts on stages?}

The Malady of Death could be staged in the theatre. [...] Only the woman would speak her lines from memory. The man never would. He would read the text, either standing still or walking about around the young woman. The man the story is about would never appear. Even when he speaks to the young woman he does so only through the man who reads his story. Acting is replaced here by reading. I always think nothing can replace the reading of a text, that no acting can ever equal the effect of a text not memorised. So the two actors should speak as if they were reading the text in separate rooms, isolated from one another ${ }^{13}$.

$\mathrm{L}=$ Listener.

$\mathrm{R}=$ Reader.

As alike in appearance as possible.

Light on table midstage. Rest of stage in darkness.

Plain white deal table say $8^{\prime} \times 4^{\prime}$.

Two plain armless white deal chairs.

$\mathrm{L}$ seated at table facing front towards end of long side audience right. Bowed head propped on right hand. Face hidden. Left hand on table. Long black coat. Long white hair.

$\mathrm{R}$ seated at table in profile centre of short side audience right. Bowed head propped on right hand. Left hand on table. Book on table before him open at last pages. Long black coat. Long white hair.

Black wide-brimmed hat at centre of table.

${ }^{13}$ M. Duras: The Malady of Death. English translation B. Bray. New York 1986, p. $58-59$. 
Fade up.

Ten seconds.

$\mathrm{R}$ turns page.

$\mathrm{R}$ : [Reading.] Little is left to tell ${ }^{14}$.

Damit möchte ich eine Zeitspanne der Intoxikation durch fremde Texte konservieren, eine Auswahl von Werken zur Schau stellen, die meiner Meinung nach wichtig für die Kunst sind (oder zumindest für mich selbst) und diese auf den folgenden Seiten laut vorlesen, nicht so, wie man sie vorlesen solle, sondern der eigenen Neugier, der eigenen Lust, der eigenen Naivität und der Wut folgend ... um sich von dort ausgehend weiterzubewegen. Dieses Buch ist eine LEKTÜRE, keine Auseinandersetzung. Ich bestehe auf diesem Unterschied ${ }^{15}$.

What kind of reading aloud of their texts did those authors call for in the above mentioned passages? Duras writes a novella The Malady of Death, which is not really a novella, but a text to be put on stage through performative reading, which to her mind could never be substituted by acting. Beckett establishes reading aloud as the dramatic action in Ohio Impromptu, so that the staging of this play is almost impossible to imagine without the use of reading as a performative strategy. And Sajko writes a theoretical book Auf dem Weg zum Wahnsinn (und zur Revolution) - Eine Lektüre and insists that it is reading aloud rather than theoretical discussion. Her references and sources for the book, although theoretical, could also be regarded as poetry: "da man sie als Poesie liest, laut - oder mit Frechheit oder mit Bewunderung"16. In this book, Sajko is exhibiting and exposing some of her favorite theoretical books revolving around topics of madness, artistic creation and literature:

Was mache ich? Ich stelle Bücher aus und lese laut vor.

Im Jahr 1967 hat Joseph Kosuth in seiner ersten selbstständigen Ausstellung in der Galerie Lannis in New York Bücher ausgestellt. Die Arbeit trug den Titel »Fifteen People Present Their Favourite Book«. Man könnte sagen, dass ich die Tradition fortsetze: Durch das Ausstellen von Bücher stelle ich mich selbst aus. Ich befürchtete keinen ästhetisch-theoretischen Mechanismus erklären zu können außer der Lektüre selbst - ich lese wegen der Bomben und wegen der Zünder ${ }^{17}$.

${ }^{14}$ S. Bескетт: Ohio Impromptu. In: The Complete Dramatic Works. London 2006, p. 382-383.

${ }^{15}$ I. Sајко: Auf dem Weg zum Wahnsinn (und zur Revolution) - Eine Lektüre. German translation A. Bremer, J. Marijanovic. Berlin, Matthes \& Seitz, 2015, p. 7.

${ }^{16}$ Ibidem, p. 136.

17 Ibidem, p. 226. 
By following Koshut's and Sajko's ideas on exhibiting books, one could further ask: what kind of stage directions must a playwright write in order to instruct the director, the reader, or herself when reading aloud, to approach their texts in the most suitable way? Maybe it is about finding the way of using stage directions as if they were a site of a playwright's true battle ground: "Jeder findet einen eigenen Kampfplatz - meiner hat sich zwischen den Klammern (Didaskalien)zusammengepresst"18. What is the relation between stage directions in Rose $^{*}$ and the subsequent staging of the text? In Rose**, Sajko reads the line: "The quiet people will burn up quietly", then she approaches the audience, looks directly at them and says: "That's what the audience must be told. Eye to eye. Mouth to mouth. In person"19. In Rose*, the last sentence is clearly bracketed as a stage direction. In classical theater, an actress or an actor playing one of the "speaking positions" in the play would probably take this stage direction into account and act accordingly - they would look at the audience while saying the line which is preceding it, without uttering the stage direction by which they were instructed to do so. Sajko subtly disturbs the hierarchies immanent to theater making: first of all, she is the one that gave herself the instruction to deliver a certain line in a certain way. Secondly, she then does not even follow her own instruction - actually, she keeps reading the line in the manner in which she read until that point - with her eyes fixed on the text placed on the music stand in front of her. Just then, by looking at the audience when delivering the stage direction, she emphasizes the way in which the already delivered line should have actually been read. Additionally, in this way she makes the staging process transparent - in the same manner in which she writes her own text about the text in Rose*, she also makes her own performance about the performance in Rose $e^{* *}$. Both Rose* and Rose $e^{* *}$ consist of traces of the processes of their respective geneses.

\section{From the self-referential reading to the music performance}

Numerous are authors whose discomfort of being watched while reading their texts is obvious. On the other hand, we witness book fairs, literary evenings and festivals where white male heterosexual authors read they work with joy and self-assurance and audience members, otherwise silently reading in solitude, enjoy and fetishize the presence of the author's body. Both the reluctance to perform and the possibility of fetishization of authors (or their books) collapse in Sajko's concept of "self-referential read-

\footnotetext{
${ }^{18}$ Ibidem, p. 280.

19 I. SAjко: Rose is a rose is a rose is a rose..., p. 28.
} 
ings". In a trailer for her 2009 performance Scenes with an apple Sajko states: "That girl on stage, she wrote the play. If you don't know that, you could think that I am an actress with a bad accent" ${ }^{20}$. Sajko, being both novelist and dramatist, is well accustomed to public appearances on book fairs and literary evenings. Nevertheless, she chose the apparatus and the frame of theater as a space for her self-referential readings. What is the first and most obvious difference between the literary evening and reading in theater? It is, as Sajko jokingly proposes, the possibility to confuse the audience about the privileged authorial position: Is this girl just a bad actress? In procedures of literary evenings, the possibility for such confusion is minimized - there is almost always a moderator who presents the author and her biography, prior to the reading. By choosing the frame in which she leaves space for uncertainty to emerge regarding her almost "total" authorship, Sajko actually desacralizes and defetishizes the ever-elevated and hierarchical position of the author. For the audience members who did not read the program for the performance, she might as well be "only" performing. Moreover, by reading and not declaiming previously memorized lines, she creates the possibility for even more confusion and questions to arise among the members of the audience: Is this a rehearsal or a piece? Are the performers just poorly prepared? Sajko strongly affirms reading aloud as an autonomous theatrical act, that is to say, as a strategy to be incorporated in a fully realized theater production and not only employed in the phase of rehearsing:

I really think that reading itself, in public, in front of others is a legitimate theatrical act. And for me that is incredibly interesting. And the very fact that you have someone on stage, with a text in front of them, was for me a small impudence, a thing that I was allowed to do and still claim that it is theater. And that it doesn't at all mean that I am poorly prepared, but something completely else ${ }^{21}$.

It is the specificity of performative reading that, although it abolishes the illusion and the fourth wall to a certain extent, it still remains performative and theatrical. Performative reading appropriates theatrical and performative mechanisms precisely through making them transparent. And this transparency opens a space for an oral reading practice in which the audience is not being convinced by the rhetorics of the reader and of the reading,

${ }^{20}$ Video mp4 trailer: An apple is not an apple - jabuka nije jabuka. Conceded to me by Sajko, 00:39s.

${ }^{21}$ Video documentation of the artist talk: Cruising sa Srđanom Sandićem: Ivana Sajko. https://www.youtube.com/watch? $\mathrm{v}=\mathrm{wHXh} 2 \mathrm{rBhN8E}$, minute: 38. English translation T. ŠLJIVAR [access: 13.10.2017]. 
but made aware of performative and rhetorical mechanisms they witness when being read to in theater spaces.

\section{Reasons for the self-referential reading}

Sajko began her project of "self-referential readings" together with the musician Vedran Peternel in 2005 in Zagreb, when she performed two of her plays - Woman-bomb and Archetype: Medea by reading them aloud on stage. Simultaneously with reading, she also commented on processes of writing and performing and, thus, produced new textual materials "live", while Peternel created soundscapes for the pieces:

The self-referential reading is perhaps pure exhibitionism institutionalized by a single discourse on the process, yet at the same time, in the performance of this memory of processuality, I create new relationships and prove the vitality of even that completed, packaged body. I express all of its potency whilst, for instance, explaining the history of "Woman-bomb", improvising new passages based on existing strategies, but also based on actual documents; or whilst writing stage directions for "Archetype: Medea", which talk about the rehearsals for the premiere performance of the text, knowing that those stage directions will offer me the opportunity to replicate each following performance of "Archetype: Medea" or the reading that preceded it, to try to repeat it, act a few scenes, retell audience reactions to a specific play and, in this way, construct a collage within the space and time of performance, driving forwards, generating a new bond between the author and the text through methods and processes, a new text in which, talking about myself, I also talk about the world and the art in which I am immersed ${ }^{22}$.

The beginning of this duo's collaboration was another project - Mass (for election-day silence) from the year 2004, in which Sajko occupied a more traditional role of the director, instructing actors and dancers to be (bodily) rhythmed and choreographed by the pace of their own reading and speech. Mass (for election-day silence) was a performance in which it became possible for the speech (and reading): "to become a howling rhythm which choreographs us, filling the space of the stage, permeating each pore of the witnesses in the audience"23. Self-referential reading is also a strategy Sajko

${ }^{22}$ I. SAJко: My strength is in my speech. "Frakcija - Performing Arts Magazine" 2005, no. 37/38, p. 43. English translation M. Simić.

${ }^{23}$ Ibidem, p. 44. 
employs to evade common post-writing anxiety in situations when writers are expected to revisit their texts after they have been written:

Burrowing into the meaning of the text within myself and conquering it, it does not sink deeper into me, it actually leaves me. When I later come across it in the world and on the market, I wonder about how to touch it again and for that touch to be equally essential [...] as it was in the moment of its generation. How to discover a new Eros between the two of us who have, completing each other, articulating each other to the last limits through every single figure and trope, spent each other. [...] (This excess of familiarity usually kills the love affair.) [...] I don't know where to go, except back, into selfreferential reading. If I want to generate this text in another medium, for instance through my own performance or a play, I have to find a way to avoid that which I am certain of - the completed textual body which, to be sure, opens itself up to an innocent reader or a spectator, yet in front of me it keeps silent as a definiteness which I need to shatter in order to speak again. [...] I discover the eroticism of creation in talking about the process $[\ldots]^{24}$.

Self-referential reading developed into a more structured format from which performances Scenes with an apple and Rose ${ }^{* *}$ emerged. In those two pieces, improvised textual or musical scores were no longer there; however, the reading in them was still not replaced by acting, and playing the music did not develop into a form of a concert, nor it became an illustrative background for the text. What Sajko denotes as her text's "exclusive position" towards her, which is "so totalitarian" 25 , is actually being subverted through the practice of performative reading. The question of the totalitarian relation of mutual ownership between the author and the text which "kills the love affair" and kills the erotics of creation is resolved in the practice of reading aloud. A writer and a scholar M. Leahy, from the perspective of an artist operating among divergent textual and performative practices, explains this effect as follows:

The text presented in the reading is the reader's (inasmuch) as she delivers it, but she need not claim to own it, or to have special access to its meanings or any intentions of/for the text. (This is not to say that the reader doesn't know the procedure employed to generate the text, or the sources of the text, or even the impulses or desires that

\footnotetext{
${ }^{24}$ Ibdem, p. 42-43.

25 Ibidem, p. 43.
} 
led to the writing of the text). The audience comes into possession of the text (with the reader) in the reading, and their prior knowledge of language, or words, of cultural material, their desires for and expectations of the work, their intentions will impact on their hearing of it in that present ${ }^{26}$.

Performative reading, therefore, exempts both the audience and the reader-author from the ownership relations towards the text. Text is being revealed to both instances equally and simultaneously through their capacities to read and to listen and to bodily sense what is being read aloud.

\section{Temporality of the performative and self-referential reading}

I would now like to describe and compare the two temporalities - one of the writing and reading (of the text) and the other of performing (of the same text). Let us first read the passage from Postdramatic theatre in which Lehmann makes the strict distinction between the temporality of the (silent) reading and the temporality of the staging:

Theater is familiar with the time dimension of the staging peculiar to it. While the text gives the reader the choice to read faster or slower, to repeat or to pause, in theatre the specific time of the performance with its particular rhythm and its individual dramaturgy (tempo of action and speech, duration, pauses and silences, etc.) belongs to the "work". It is a matter of the time no longer of one (reading) subject, but of the shared time of many subjects (collectively spending time $)^{27}$.

This type of differentiation collapses in performative reading where reading coincides with performing, and in this manner both temporalities collide into a single one. And although the temporality is a single one, the difference between the content of the text and the content of the performance is still very tangible, and it creates a certain kind of sensorial distortion. This effect of the certain "double vision", the gap, the clash and collision between the text that is being read aloud and the performance which in its essence is that very reading aloud, requires multifocal attention from the audience.

${ }^{26}$ M. LeAHY: What is it here now I can persuade you of? scraps towards a rhetoric of poetry performance. "Frakcija - Performing Arts Magazine" 2005, no. 37/38, p. 55.

${ }^{27}$ H.-T. Lehmann: Postdramatic theatre. English translation K. Jürs-Munby. London and New York, Routledge, 2006, p. 153. 
How is this paradoxical quality of oneness and duality manifested in the relationship between $\operatorname{Rose}^{*}$ and Rose ${ }^{* *}$ ? Multiple temporalities are already employed in the content and form of Rose*: love encounter happens in a club on a Wednesday evening, and on Thursday early morning all newspaper headlines report on a dreadful explosion of a bus which occurred the night before. Sajko obscures her readers' perception by distorting the chronology: "they" (and it is also not clear if the pronoun designates the love couple or any other indeterminate number of inhabitants of the province) got on the bus and fell asleep while reading the morning newspaper which had already reported on a dreadful event that was yet to happen and in which they would die or died or were about to die:

They get on the bus.

The one from the record. On the front-page. Ablaze.

The one that is late. An hour. And more.

And they are heavy-eyed.

To be asleep before they even get home.

Head on the window-glass and papers in hand. Like some morons. The early edition which spells it all out.

That they were dog-tired and fell asleep, for tomorrow's another working day.

Got to get up early.

No one will ask them about today tomorrow.

And they worked today too.

Got up early too.

No one asked them anything today.

And it's not Friday.

Not even Thursday yet.

But soon. Any moment.

And no one will have asked them anything.

They'll get on the bus. Take a seat. Fall asleep.

Never to wake up ${ }^{28}$.

In Rose**, Sajko also insists on the uncertain time frame which is operational in the play. Onstage, she sometimes makes a movement or a bodily scenic action before she reads the line which alludes to it. Her corporeal performance at times precedes her reading performance. She wears a red dress (like roses) and she is 8 months pregnant. Her possible private love encounter happened long before the performance and through performing, the disjunction of the real-life encounter is revisited and brought into the

${ }^{28}$ I. SAjко: Rose is a rose is a rose is a rose..., p. 26-27. 
presentness, the here and now in the theater. Writing the text happened, too, and it is necessary to find an equally exciting process to be able to perform it, here and now in the theater. Love happened, too, and it is necessary to talk about its beginning, here and now in the theater. The bus exploded, but "characters" (i.e. speaking positions) who died in the accident are revisiting the event here and now in the theater.

Temporality and rhythm of a body which writes influence the temporality and rhythm of a text which the body writes. Sajko claims that the written text is rhythmed by her own body and that "punctuation is proportional to the length of her breaths" ${ }^{\prime 29}$. L. Robertson in her essay Time in Codex ${ }^{30}$ explains that when one reads, two temporalities are operational - one of the reader and one of the book: "I read to sense the doubling of time: The time of the book's form, which pertains to the enclosure and topology of rooms, allegories, houses, bodies, surfaces; and the time of my perceiving, which feels directional, melodic, lyric, inflectional" ${ }^{\prime \prime 1}$. The text which was, in its gestation, rhythmed by the writer's body, in turn rhythms the bodies of performers when performed. And when it is being read silently, it equally rhytmizes the body of the reader: "Then, because of the book's time overlaying my own, reading opens a proposition. It receives in me the rhythm I didn't know I missed"32.

The text Rose*, in the moment of its completion, was in front of Sajko, the writer, as "silent as a definiteness which I need to shatter in order to speak again". Sajko, director and performer, goes back into self-referential reading and performs the text on stage by reading it aloud. For Sajko the play is an evidence of her own existence:

The text is, at least for me, the ultimate proof that I am here, at this very moment, right now, writing, putting a full stop after a statement that seems like a conclusion, while it is actually but a paraphrase of my fear of death: the text is a necessary trace of my act. Full stop ${ }^{33}$.

In the circumstances of a self-referential reading, when authors read their own texts aloud on the theater stage, the "being-at-this-very-moment" quality of writing recovers. Performing one's own text by reading it aloud could be an ultimate proof of being "here, at this very moment". The now of writing is revisited through the now of reading and performing ("Wer liest, liest

\footnotetext{
29 I. SaJKo: My strength is in my speech..., p. 42.

${ }^{30}$ L. Robertson: Nilling. Toronto 2012, p. 11.

31 Ibidem, p. 15.

32 Ibidem, p. 15.

${ }^{33}$ I. SAJKo: Rose is a rose is a rose is a rose..., p. 12.
} 
jetz $\left.t^{\prime \prime 34}\right)$, and also through the now of listening. Sajko summarizes her artistic approach towards writing, directing and performing and intersections between those disparate and yet perpetually converging activities, as follows:

Die Körper des Autors, der Gestalt und des Schauspielers werden nun durchdrungen, ausgetauscht, sie springen von einem auf den anderen über und überqueren dabei verschiedene Raum-Zeit-Grenzen sowie verschiedene Ebenen auf der Illussionsskala: von der Schaustellung, die nicht auf das eigene Schaustellen verweist, über die Theatralisierung dieser Schaustellung, bis hin zu der Stufe, auf der sich diese Schaustellung vor das stellt, was gezeigt wird ${ }^{35}$.

By working in this manner it really becomes possible for Sajko to accomplish her desire for the text to equally belong to her and to her characters: "The same text was assigned to both myself and the characters".

The initial interest in writing the M.A. Thesis out of which this article has been reworked came from my own authorial distress and anxiousness about failing to find the appropriate means of presenting my texts on stage and in literary readings. The notion I used and further developed as a "performative reading" is a conceptualization and theorization of an artistic desire. The same is true for Ivana Sajko's notion of "self-referential" reading. Leahy notices that in the artistic frame of oral reading events: "There is/are gap(s) between the self in the room before the audience speaking reading and the self/selves written onto the sheet script from which she reads" ${ }^{\prime 36}$. Concepts we propose reading strive for overcoming this gap and the other gaps too - by insisting on the sociality of such events which opposes the solitude of the silent reading. In the frame of self-referential reading, or of performative reading, it becomes possible to assign the same text not only to an author and to characters, but also to performers and to members of the audience. Reading aloud, as used by Sajko in Rose $e^{* *}$, is a performative strategy which abolishes ownership relations between the author and their text, in the same manner in which it enables author, characters, performers and the audience to share the same text in in the theater, to share it without ever owning it, to share it by listening to it:

The sociality of reading does not always or only pertain to the present; it implicates the multi-temporal generosity of politics. Within

${ }^{34}$ T. Schestag: Lesen-Sprechen-Schreiben (Kritzeln). Berlin 2014, p. 11.

${ }^{35}$ I. Sајко: Auf dem Weg zum Wahnsinn (und zur Revolution) - Eine Lektüre..., p. 110.

${ }^{36}$ M. LeAHY: What is it here now I can persuade you of? scraps towards a rhetoric of poetry performance. "Frakcija - Performing Arts Magazine"..., p. 55. 
this folded time, the person and an impersonal speech test and inflect and mix into one another. The book's darkly confected scene is a speculative, temporally striated polis ${ }^{37}$.

This almost utopian multi-temporal political polis consisting equally of texts and bodies could also possibly be substantiated on the theater stage when employing reading aloud as a performative strategy.

\section{Literature}

Bескетт S.: Ohio Impromptu. In: The Complete Dramatic Works. London, Faber \& Faber, 2006.

Duras M.: The Malady of Death. English translation B. Bray. New York, Grove Weidenfeld, 1986.

Dolar M.: A voice and nothing more. Cambridge Massachusetts, MIT Press, 2006.

LEAHY M.: What is it here now I can persuade you of? scraps towards a rhetoric of poetry performance. "Frakcija - Performing Arts Magazine". Zagreb, Center for drama arts, 2005.

Lehmann H.-T.: Postdramatic theatre. English translation K. Jürs-Munby. London and New York, Routledge, 2006.

Robertson L.: Nilling. Toronto, Bookthug, 2012.

Sајко I.: Auf dem Weg zum Wahnsinn (und zur Revolution) - Eine Lektüre. German translation A. Bremer, J. Marijanovic. Berlin, Matthes \& Seitz, 2015.

Sajко I.: My strength is in my speech. "Frakcija - Performing Arts Magazine". English translation M. Simić. Zagreb, Center for drama arts, 2005.

SAJко I.: Rose is a rose is a rose is a rose. In: Welt retten / Saving the world. English translation T. BRLEK. Graz, Steirischer Herbst, 2008.

${ }^{37}$ L. Robertson: Nilling..., p. 12. 